\title{
Scientists under the societal microscope: challenges to research integrity
}

\author{
Cientistas sob o microscópio da sociedade: desafios para a integridade da investigação
}

Científicos bajo el microscopio de la sociedad: desafíos para la integridad de la investigación

\section{Ana Sofia Carvalho ${ }^{1}$}

\begin{abstract}
COVID-19 promises to reshape every aspect of society, not excluding how science is perceived. However, it is not clear whether the authority of science and scientists will be enhanced or diminished, or whether such changes will affect mainly science as an endeavour or scientists as individuals. The aim of this paper is to analyze how a pandemic like COVID19 could undermined the confidence in science and scientist and, to underline now, more than ever, the importance of trust in science and in scientists. Two main issues will be analyzed: first, we will analyze how putting science and scientists in the spotlight could impact science and scientists and, secondly, we will go through the history of COVID treatment and research to anticipate how misconduct and breaches on responsible conduct in research could undermine trust in science with serious risks and consequences.
\end{abstract}

\section{Keywords}

Research misconduct. Research integrity. Pandemic. COVID-19.

\section{Resumo}

A pandemia da COVID-19 terá influências indeléveis em todos os sectores da sociedade, não excluindo a forma como a ciência é percecionada. No entanto, hoje, não se sabe como a confiança na ciência e nos cientistas será afectada pela pandemia e se tais mudanças afetarão principalmente a ciência como um empreendimento ou os cientistas como indivíduos. Assim, o objetivo deste artigo é analisar como uma pandemia como a COVID-19 pode afectar a confiança na ciência e nos cientistas e sublinhar, numa altura tão crítica para todos, a importância da confiança na ciência e nos cientistas. Duas questões principais serão analisadas: primeiro, como o facto de colocar a ciência e os cientistas no centro das atenções e das decisões poderá impactar a forma como a sociedade confia e acredita na ciência e nos cientistas e, em segundo lugar, a história dos progressos e retrocessos nos tratamentos e na investigação científica sobre a pandemia para, desse modo, destacarmos-mos a importância da integridade científica e, mais de que nunca, da necessidade de condutas responsáveis em investigação.

\section{Palavras-chave}

Fraude científica. Integridade científica. Pandemia. COVID-19.

\section{Resumen}

La COVID-19 promete remodelar todos los aspectos de la sociedad, sin excluir cómo se percibe la ciencia. Sin embargo, no está claro si la autoridad de la ciencia y los científicos aumentará o disminuirá, o si tales cambios afectarán principalmente a la ciencia como esfuerzo o a los científicos como individuos. El objetivo de este trabajo es analizar cómo una

\footnotetext{
1 Doutora; Professora Associada, Instituto de Ciências Biomédicas Abel Salazar, Universidade do Porto, Porto, Portugal; Consultora de Ética, Hospitais CUF, Porto, Portugal. https://orcid.org/0000-0003-1132-8880. E-mail: anasofiapintodecarvalho@gmail.com; ana.s.carvalho@cuf.pt
} 
pandemia como COVID-19 podría socavar la confianza en la ciencia y los científicos y, subrayar ahora, más que nunca, la importancia de la confianza en la ciencia y en los científicos. Dos temas principales serán los que analizar: primero, analizaremos cómo poner a la ciencia y los científicos en el centro de atención podría impactar a la ciencia y los científicos y, en segundo lugar, repasaremos la historia del tratamiento y la investigación de COVID para anticipar cómo la mala conducta y las infracciones a la conducta responsable. en la investigación podría socavar la confianza en la ciencia con graves riesgos y consecuencias.

\section{Palabras clave}

Mala conducta en la investigación. Integridad en la investigación. Pandemia. COVID-19.

\section{Introduction}

Ever since the first genome sequence of the novel coronavirus was released in February 2020, scientists have been supercharged. The speed and volume of discovery over the past year have been outstanding, with researchers managing to unravel the molecular details of the virus, understand how it spreads and who is most at risk, and invent tests, drugs, and vaccines to tackle it (1). The public has seen what scientists can do under pressure...

However, this cannonball run might highlight the wicked side of science. Together with pandemics we should considered that research misconduct seems like another epidemic that must concern and occupy scientists, research institutions and the entire research endeavor. In fact, this huge system produces not only knowledge and elucidation; if it is true that scientifically has become, for all intents and purposes, a form of epistemic praise which means strong, reliable, safe, it is also true that such exaltation has hastened its vulnerable face "science as fallible, imperfect and sometimes corrupt" (2). The impact of this pandemic on this complex equation will, undoubtedly, leave indelible marks on science and scientists and, more importantly, in the way society perceives the scientific knowledge.

Good scientific practices could, indeed, be challenged by COVID-19 pandemics; in fact, COVID will impact everything. COVID-19 promises to reshape every aspect of society, not excluding how science is perceived. But, it is not clear whether the authority of science and scientists will be enhanced or diminished, or whether such changes will affect mainly science as an endeavour or scientists as individuals (3).

It is, therefore, not clear on how bringing science to the frontline of public decisions would or not affect trust that is indeed the core of scientific endeavour.

The aim of this paper is to analyse how a pandemic like COVID-19 could undermined the confidence in science and scientist and, to underline now, more that ever, the importance of trust in science and in scientists. Responding to this will not be straightforward and 
responsibility in COVID-19 research, treatments and clinical trials can have a huge impact on how the public perceives trust in science and how measures and future policies and treatments could or not be implemented with efficacy and efficiency.

There are two main issues that we should analyse that are related with trust and that could have a huge influence in the future of scientific endeavour and, in fact, in the future of all of us. So mainly, we will divide this paper in two different moments: First, we will analyse how putting science and scientists in the spotlight could, if not adequately considered, represent a burden to science and scientists. We will present some recommendation from the joint statement on scientific advice to European policy makers concerning the COVID-19 pandemic (4) presented by the European Commission's independent Group of Chief Scientific Advisors (GCSA), the European Group on Ethics in Science and New Technologies (EGE) and Peter Piot, special advisor to the President of the European Commission, Ursula von der Leyen. Secondly, we will go through the history of COVID treatment and research to anticipate how misconduct and breaches on responsible conduct in research could undermine trust in science with serious risks and consequences to the word.

\section{COVID-19 and evidence: the risks to science and to scientists}

Francis Collins, Director of the National Institutes of Health stated: "We did science in ways that people did not think we could, driven by this sense of urgency, which we all say that every day counts. This is a pandemic that is taking lives and destroying economies, and there's no excuse for anybody arguing for delay." Of course all of us agree that "everyday counts" and that "there's no excuse for delay", however, more than ever society must maintain trust is science (1).

The COVID-19 pandemic is considered as the most crucial global health calamity of the century and the greatest challenge that the humankind faced since the II World War. SARS-CoV-2 have been found to be responsible for occurrence of this disease and for the major public health crisis throughout the world. The impacts of this tsunami, from the point of view of mortality, morbidity for people and the economy, is and will be for a long time overwhelming. According to the report of the World Health Organization (WHO) of March 3 2020, the current outbreak of COVID-19 has affected over 115 million people and killed more than 2.5 million people throughout the world. The SARS-CoV-2 virus is a pathogen previously unknown to science and medicine. Therefore, there is still a lack of information on the virus itself, the spread of the disease, the herd immunity and the causes of excess deaths. 
This pressure situation could, indeed, reversing the secular trend of challenging the value of scientific expertise and the scientific imperative of evidence-based. The coronavirus crisis has put a spotlight on the importance of science in supporting our nation's well-being $(6,7)$. However, the evidence from science in terms of research and from medicine in terms of treatments, which is often required at short notice and is crucial to help develop sound public policies and treatments is, in the context of COVID-19, uncertain or inexistent.

We could argue that COVID-19 impacts will foster the scientific community to reframe the research paradigm: from evidence-based research to fit-for-purpose research (7). The 20th-century logic of evidence-based research/medicine, in which scientists pursued the goals of certainty, predictability and causality, remains useful in some circumstances (e.g. the drug and vaccine trials). However, in a puzzling situation, like this pandemic, the question driving scientific inquiry is not "what is the effect size and is it statistically significant once other variables have been controlled for?" but "does this intervention contribute, along with other factors, to a desirable outcome? (7) So, the model of evidence-based policy, in the case of COVID-19 is challenged and, therefore, scientific advisors together with the politicians should take into consideration all these new variables regarding communication to the public.

As previous stated, scientific knowledge of a pandemic such as COVID-19 is often uncertain and tentative, and changes over time. Communicating uncertainty and complexity to policy makers and to the public at large can be challenging, but is crucial if trust in politicians and their scientific advisors is to be maintained (4). Uncertainty leads to dynamic adjustments of the decision, and the best decision today may not be the best tomorrow. This means that the decision process is based on uncompleted information and that we should be clear on this within the communication strategy. Scientific and medical advisors need to provide clarity about what is known, partially known, unknown, and unknowable (4). This is quite problematic due to the tendency to keep the same policy, even if not really well-adapted anymore, so as to avoid any criticism on initial lack of vision (8). This is quite problematic within this pandemics scenario.

Although it is understandable that governments should do what they want rather than what a group of scientists suggests they should do, both, scientists and governments must be accountable and transparent regarding their options to the public. Therefore, and because so many onerous demands, that put in questions essential ethical principles and constitutional guarantees, are made on personal behaviour, trust of the society in in their scientific and political leaders is, within this situation, particularly critical. "Trust is only 
possible if the science advice given by official advisors is open and transparent, accountable and is based on the highest quality" (4). It also needs to be well communicated to the public by the scientists and politicians. In the same line, it is important to underline that opinion makers should avoid talking about the issues that they cannot grasp especially when their interventions create restlessness within the public.

Being open and transparent allows the evidence upon which the advice is based to be publically assessed, and makes it clear whether political leaders indeed take the science seriously and if not, it forces them to justify their actions. Being open also allows other scientists to challenge evidence and interpretation, which is often required when knowledge is tentative, uncertain, and complex. (4)

The COVID-19 pandemic has highlighted disagreements among scientists, leading to criticism from politicians and the public. Even if surfing in uncertainty is part of the scientist's everyday work, for public it is quite troubling. It has renewed long-standing concerns that lay perceptions of scientific disputes diminish the regard in which scientific findings are held and further "misunderstanding of how science operates and/or...[lead] people to ignore scientific advice" (9). It has put on display leaders' "longstanding practice of undermining scientific expertise for political purposes" and of engaging in "denigration of scientific expertise and harassment of scientists" (10). In the current fast-moving pandemic, however, the logic of fit for purpose science have to prevail since the cost of inaction is counted in the grim mortality figures announced daily, Therefore, implementing new policy interventions in the absence of all evidence has become both a scientific and moral imperative (7). This, of course, could have a significant impact on research integrity.

\section{Research misconduct and COVID-19}

Ethically objectionable behaviors are not new, however we must try to guarantee that their increase will not be another side effect of the pandemic. Undeniably, the massive scientific production and its diffusion during this pandemic, make this phenomenon especially significant and, therefore, the oversight of bad practices must be more rigorous. Furthermore, it is inevitable that lockdown measures changed, significantly, the way researchers work use to be done; the physical presence and the group meetings have been replaced by zoom and being alone in the research facilities is almost mandatory.

The reasons why bad scientific practices occur can be grouped around three factors: i) individual, associated with inappropriate behaviour by members of the scientific community; 
ii) organizational, related to the nature of interpersonal relationships within a research organization, and iii) structural, related to how the science and scientists are evaluated and funded (11). It's easy to realize that this pandemic will have influence in all the three factors.

In comparison with the SARS outbreak in 2003, the COVID-19 pandemic has led to substantially more scientific publications during the first year. Preprints have become the medium of choice. The rapidly increasing number of publications combined with the urgency to quickly understand the new pathogen presents a significant challenge for maintaining the integrity of the underlying evidence, or fit-to-purpose base, and to ensure that research is conducted according to global standards of research integrity (5).The COVID-19 pandemic was associated with a high index of publication that, obviously, favored the high level of retractions, including journals with the highest credibility in health science. Retractions can have consequences for health policies, mainly public ones, and could lead to the rejection of science and medical results by the public and by the politicians. Also, the undeniable therapeutic potential of COVID research that, indeed, could generate greater economic, societal, media impact could be considered a high-risk factor to research misconduct.

Public distrust in science and scientists during and following a pandemic can be a product both of individuals' or organisational' backgrounds and, as stated in the previous part of the text, of miscommunication by the scientific community. Such miscommunication, including conflicting statements by different experts, is more likely in crisis periods when the pressure to quickly produce and disseminate scientific findings is intense. Members of the public who are not familiar with the scientific process may interpret the conflicting views of scientists and criticism of some studies by the authors of others as signs of bias or dishonesty. If you're a researcher, uncertainty and contradicted results make perfect sense, however, "if you're out there in the public, just consuming sound bites, that makes it look like we don't know what we're talking about" (1).

Therefore, in this part of the text we will present some issues that could contribute to reduce confidence in individual scientists, worsen perceptions of their honesty, and weaken the belief that their activities benefit the public. Unfortunately, we already have some misconduct cases; however, currently, any misconduct, any error, any deceit, can result in harm to patients as well harm to the cause of science, as the Wakefield saga so properly reveals. Different theories explaining the aetiology of autism, one that has achieved widespread popularity among the general public is the involvement of the measles, mumps, and rubella (MMR) vaccine as the causation of autism. In 1998, Andrew Wakefield and 12 of 
his colleagues published in The Lancet, which suggested that vaccine may predispose to behavioural regression and pervasive developmental disorder in children. Despite the huge amount of research integrity and research ethics flaws, the impact of the paper, especially in parents, has been tremendous and its consequences are still important. Terribly, parents across the world did not vaccinate their children out of fear of the risk of autism, thereby exposing their children to the risks of disease and the well-documented complications related thereto. Measles outbreaks in the UK in 2008 and 2009 as well as pockets of measles in the USA and Canada were attributed to the no vaccination of children. (12).

The Wakefield fraud is likely to go down as one of the most serious frauds in medical history and something similar regarding the COVID-19 will be disastrous. Therefore, more than ever, scientists and companies who publish their research or are developing new tentative drugs or vaccines, have an ethical responsibility to ensure the highest standards of research design, data collection, data analysis, data reporting, and interpretation of findings.

There are now more than 150 million confirmed COVID-19 cases worldwide and the death toll of the global pandemic has surpassed 2 million. The pandemic has also had enormous social and economic impacts globally, and continues to challenge families, communities, health systems, and virtually every aspect of society. Therefore, efforts to develop COVID-19 vaccines are well underway, and protecting the scientific integrity of the process is paramount. The trials must be - and must be seen to be - free of political interference, carried out with the highest scientific and ethical rigor, and allowed to proceed until the safety and efficacy of each candidate vaccine has been thoroughly assessed. The ultimate goal is global distribution of and equitable access to effective vaccines that can help slow, and eventually end the pandemic (13).

The speed and volume of data that have been published in the past few months on COVID-19, emphasise the long-recognised importance of maintaining research integrity. It is well known that the systems and processes for maintaining integrity in research are not without their flaws. The current crisis has made these flaws more apparent due to their potential for immediate impact on policy making and resulting consequences for public health. Some poorly designed studies have already been published in the specialist literature. Controversial statements and unproven claims from researchers have appeared in the media. Some of these have been immediately questioned, leading to confusion and loss of trust among the public $(5,14)$. 
The world was stunned when The Lancet, medicine's most respected scientific journal, retracted a blockbuster article within two weeks of its publication over data credibility.

The public, alarmed by a retraction about COVID-19 treatment from the world's most stringent standard in scientific publication, coined it Lancet-gate. The retracted article reported a chilling mortality risk among COVID-19 patients treated with anti-malarial drugs chloroquine (CQ) or hydroxychloroquine ( $\mathrm{HCQ}$ ). The article made many believe the drugs might have caused more deaths than cures. The research seemed convincing. It was based on a gigantic sample size of close to 15,000 patients from 671 hospitals around the world who had been treated with the drugs. But it took only days for scientists and the public to spot something fishy, involving the credibility of both the data and the institution responsible for the data collection and management (15).

Of course, these are difficult times and we need rapid results to save people, and thus some journals are asking editors to accept without delay submitted manuscripts that in their judgment can stand as Life papers, even if they feel that the manuscript would be stronger (9). Although, the truth is that accepting everything is not helping medicine, quite the opposite. Indeed, reducing the rigor of studies would not lead to any benefits, may distort COVID-19 knowledge, and postpone a real solution for pandemic and create public mistrust in a possible solution for the diastase. Effective epidemic control depends on public compliance with government mandates based on scientific advice. For example, trust in scientists recommending policies such as mask wearing, social distancing, lockdowns and mass vaccination will be associated with greater compliance with those recommendations. Also, as some countries have begun to ease lockdown measures and others consider what approach to take, the reliability of the research used to make these decisions will be crucial. The use of flawed studies that lacked proper peer review by predisposed advisory committees could reignite the pandemic and lead to further economic instability. The millions currently being invested in research will be of little use if it is not conducted, published and used with integrity (5).

The urgency to understand and overcome the pandemic may tempt researchers to ignore the due consideration for ethics and integrity standards and protocols, or to cut important corners in research to quickly reach conclusions in order to impact rapid decision making. While fast results are clearly required in this critical situation that is no excuse. Science without honesty is not science and as the European Network of Research Integrity Offices (ENRIO) stated "the research community have to respect the highest integrity 
standards in performing and reporting research for the benefit of humanity now and in the future" (16).

\section{Conclusion}

The reputation of the scientists and pharmaceutical industry has improved during the pandemic, as the public closely followed the development of new data, new advice and new treatments. Scientific community's rapid mobilization also highlighted that science is collaborative, works across borders, and is performed by diverse teams (1). All of the sudden everyone is watching scientists, and they are seeing all the breakthroughs but also the messiness of how science happens (17). The rapid evolution of the knowledge related with Coronavirus, the data on the new tentative treatments and vaccines for COVID-19, mixed messaging from politicians, a torrent of misinformation and fake news, political interference in science, and peak levels of polarization, fear and distress, threaten to disintegrate public trust in science.

The pandemic has placed science under the public microscope. Never before has a scientific issue so immediately and directly affected the lives of everyone at the same time (17). The global crisis caused by the Covid-19 pandemic has stunned society, indeed, one of the many lessons of this crisis is that it will have confirmed the urgent need to stabilize the foundations of fully responsible research practices, throughout a research ecosystem that respect the highest integrity standards in performing, reporting and funding research for the benefit of humanity now and in the future.

\section{References}

1. Halford B, Howes L, Widener A. How COVID-19 has changed the culture of science. C\&EN. 2021 Jan 25;99(3). Available from: https://cen.acs.org/biologicalchemistry/infectious-disease/How-COVID-19-has-changed-the-culture-of-science/99/i3

2. Portugal. CNECV (Conselho Nacional de Ética para as Ciências da Vida). 2019. RECOMENDAÇÃO SOBRE INTEGRIDADE CIENTÍFICA Available from: https://www.cnecv.pt/pt/pareceres/integridade-na-investigacao-cientifica-recomendacao1

3. Eichengreen B, Giray Aksoy C, Saka O. Revenge of the experts: Will COVID-19 renew or diminish public trust in science? Journal of Public Economic. 2021;193:104343.

4. By The Group of Chief Scientific Advisors of the European Commission, The European Group on Ethics in Science and New Technologies, and Peter Piot - special advisor to the President Ursula von der Leyen on the response to COVID-19. COVID-19 pandemic 
Statement on scientific advice to European policy makers during the covid-19 pandemic. 2020 Jun 24. Available from:

https://ec.europa.eu/info/sites/info/files/research and innovation/groups/sam/sam covid19-statement-v5a.pdf

5. Gopalakrishna G, Bouter L, Mayer T, Steneck N. Assuring research integrity during a pandemic. 2020 Jun 8. Available from: https://blogs.bmj.com/bmj/2020/06/08/assuringresearch-integrity-during-a-pandemic/

6. Shepherd M. The COVID-19 Coronavirus Pandemic Highlights The Importance Of Scientific Expertise. 2020 Mar 20. Available from:

https://www.forbes.com/sites/marshallshepherd/2020/03/14/covid-19-and-the-suddenrespect-of-science-expertise/?sh $=3 \mathrm{~d} 91 \mathrm{~b} 51 \mathrm{~d} 29 \mathrm{~b} 0$

7. Greenhalgh T. Will COVID-19 be evidence-based medicine's nemesis? PLoS Med. 2020;17(6):e1003266.

8. Raboisson D, Lhermie G. Living With COVID-19: A Systemic and Multi-Criteria Approach to Enact Evidence-Based Health Policy. Front Public Health. 2020;8:294.

9. Dieckmann NF, Johnson BB. Why do scientists disagree? Explaining and improving measures of the perceived causes of scientific disputes. PLoS One. 2019;14(2):e0211269.

10. U.S. National Academy of Sciences. Scientists for Science-Based Policy, 2020). Statement to restore science-based policy in government. 2020 Jun. Available from: https://scientistsforsciencebasedpolicy.org/

11. Patrão Neves MC, Casado M, Lecuona, I, Carvalho AS, Araújo J. Declaration on research integrity in responsible research and innovation. 1st ed. UNESCO Chair of Bioethics from Barcelona and Porto: Universitat de Barcelona Edicions; 2016. Available from: http://www.bioeticayderecho.ub.edu/en/declaration-research-integrity-responsibleresearch-and-innovation

12. Rao TS, Andrade C. The MMR vaccine and autism: Sensation, refutation, retraction, and fraud. Indian J Psychiatry. 2011;53(2):95-96.

13. Preserving the scientific integrity of getting to COVID-19 vaccines 2020 Oct 6 . Available from: https://www.youtube.com/watch?v=Q05aYCaA6Ks

14. Boschiero MN, Carvalho TA, Marson F. Retraction in the era of COVID-19 and its influence on evidence-based medicine: is science in jeopardy? Pulmonology. $2021 ; 27(2): 97-106$.

15. Sasongko TH. Lancet-gate in the COVID-19 pandemic era: is it all right for science to be wrong? 2020 Jun 19. Available from: https://theconversation.com/lancet-gate-in-thecovid-19-pandemic-era-is-it-alright-for-science-to-be-wrong-140715

16. ENRIO (European Network of Research Integrity Offices. ENRIO Statement: Research integrity even more important for research during a pandemic. 2020. Available from: 
http://www.enrio.eu/enrio-statement-research-integrity-even-more-important-for-researchduring-a-pandemicl

17. Cross R. Will public trust in science survive the pandemic? C\&EN. 2021 Jan 25; 99 (3). Available from: https://cen.acs.org/policy/global-health/Will-public-trust-in-science-survivethe-pandemic/99/i3

\section{Como citar este artigo}

Carvalho AS. Scientists under the societal microscope: challenges to research integrity. Cadernos Ibero-Americanos de Direito Sanitário. 2021 jul./set.;10(3):39-49.

https://doi.org/10.17566/ciads.v10i3.795 